\title{
First confirmed record of an established population of green swordtail (Xiphophorus hellerii Heckel, 1848) in Europe
}

\author{
Pencho Pandakov ${ }^{1, *}$, Zhivko Barzov $^{2}$, Radoslav Moldovanski ${ }^{3}$ and Helena Huđek ${ }^{4}$ \\ ${ }^{1}$ University of Forestry, Sofia, Bulgaria, 10 St. Kliment Ohridski Blvd., 1797 Sofia, Bulgaria \\ ${ }^{2}$ Iskar Str. 18, Asparuhovo Res. Quarter, 9003 Varna, Bulgaria \\ ${ }^{3}$ Bulgarian Society for the Protection of Birds, Yavorov complex, bl. 71, ent. 4, app. 1, Sofia 1111, Bulgaria \\ ${ }^{4}$ Leibniz Institute of Freshwater Ecology and Inland Fisheries (IGB), Müggelseedamm 310, 12587 Berlin, Germany
}

Received: 23 February 2021 / Accepted: 28 July 2021

\begin{abstract}
The green swordtail (Xiphophorus hellerii) is a freshwater and brackish water fish native to North and Central America. It experiences wide human-traced introduction around the world, mostly due to aquarium release. Individuals of the green swordtail population from the warm spring with artificial origin located in Asparuhovo district, Bulgaria, were collected. The invasiveness screening tool for non-native freshwater fishes (FISK v2) calibrated for the Balkan region was used to assess potential invasion risk of the green swordtail to the coastal freshwater bodies of the Eastern Balkans. This study is the first confirmation on an existing self-sustained population of $X$. hellerii in Bulgaria and respectively in Europe. Climate change and the trend of warmer winters are prerequisites for the acclimatization of this species to the temperature out of the studied thermal spring. Therefore, the potential of the green swordtail to colonise new habitats is increasing with such facilitated acclimatization. We conclude that the green swordtail poses a high risk to become the next new invasive species in Southern Europe.
\end{abstract}

Keywords: Bulgaria / non-indigenous fish species / warm spring / fish introduction / ornamental fish / aquarium release

Résumé - Premier relevé confirmé d'une population établie de «porte-épée » (Xiphophorus hellerii Heckel, 1848) en Europe. Le porte-épée (Xiphophorus hellerii) est un poisson d'eau douce et d'eau saumâtre originaire d'Amérique du Nord et d'Amérique centrale. Il fait l'objet d'une large introduction par l'homme dans le monde entier, principalement en raison de relâchers d'aquarium. Des individus de la population de porte-épée provenant de la source chaude d'origine artificielle située dans le district d'Asparuhovo, en Bulgarie, ont été collectés. L'outil de dépistage du caractère envahissant des poissons d'eau douce non indigènes (FISK v2) calibré pour la région des Balkans a été utilisé pour évaluer le risque potentiel d'invasion du porte-épée dans les masses d'eau douce côtières des Balkans orientaux. Cette étude est la première confirmation de l'existence d'une population autonome de X. hellerii en Bulgarie et, respectivement, en Europe. Le changement climatique et la tendance à des hivers plus chauds sont des conditions préalables à l'acclimatation de cette espèce à la température de la source thermale étudiée. Par conséquent, le potentiel du porte-épée à coloniser de nouveaux habitats augmente avec cette acclimatation facilitée. Nous concluons que le porte-épée présente un risque élevé de devenir la prochaine nouvelle espèce invasive en Europe du Sud.

Mots clés : Bulgarie / espèce de poisson non indigène / source chaude / introduction de poisson / poisson d'ornement / aquarium

\section{Introduction}

The green swordtail (Xiphophorus hellerii) is a freshwater and brackish water fish species that belongs to family

\footnotetext{
${ }^{*}$ Corresponding author: p.pandakov@gmail.com
}

Poecilidae (Miller, 2005). Its natural range covers territories in Belize, Guatemala, Honduras and Mexico in North and Central America (Daniels and Maiz-Tome, 2019). Green swordtail inhabit diverse habitats, including: fast-flowing streams and rivers rich in vegetation; warm springs and their effluents; weedy canals; and ponds (Froese and Pauly, 2019). 
They can also inhabit very rocky arroyos, ditches, open lagoons, and rivers with a variety of substrates, in water of various characteristics, from clear to murky or muddy, sometimes badly polluted (Miller, 2005). The green swordtail is internationally popular ornamental fish, and therefore, it experiences wide human-traced introduction around the world, in most cases due to aquarium release (Nico et al., 2021). There are more than 35 countries where it has been introduced by humans (Golani and Mires, 2000; Esmaeili et al., 2010; Maddern et al., 2011; GBIF 2019; Larentis et al., 2019; CABI, 2020). Due to its popular ornamental status, green swordtail is rarely considered as a "pest" species, though it is listed on invasive species databases (e.g. Invasive Species Specialist Group and Global Invasive Species Database) (CABI, 2020). The green swordtail has become accepted as an invasive species in Wyoming (USA), Hawaii (USA), Bahamas, Israel, Hong Kong, Queensland (Australia) (Maddern et al., 2011; CABI, 2020). In Europe, species records in the wild are limited. Holčík (1991) has reported the green swordtail introduction in former Czecho-Slovakia and Hungary, without mentioning any localities or population status. Further species reports for Czech Republic, Slovakia and Hungary (CABI, 2020; GBIF, 2019) are related to Holčík's publication from 1991. Furthermore, a review on fish introductions in Czech Republic (Musil et al., 2010) do not consider the green swordtail as introduced. Green swordtail have been reported in Germany and Italy (GBIF, 2019), but have not been reported an established population in either countries. Recently, a population of green swordtail interspecies hybrid (most likely $X$. hellerii $\mathrm{X} X$. variatus) was found in an artificial lake in Warsaw, Poland, but possible acclimatization was excluded because environmental conditions during winters are out of species preferences (Maciaszek et al., 2019). The closest known established populations of green swordtail to Europe are those in Egypt, Syria, Israel, Iran and Jordan (Golani and Mires, 2000; Esmaeili et al., 2010; Daniels and Maiz-Tome, 2019).

The study site is an outflow of a warm spring with artificial origin, approximately 300 meters-long. In the past, the spring water was industrially used by the dry-cleaning company Bagra EOOD, but at the time of this study, part of the water is freely flowing (Fig. 1). The spring is situated in the city of Varna, Bulgaria, in the district of Asparuhovo. The spring has the following coordinates N43.184153, E27.884920, with an altitude of $7 \mathrm{~m}$, and the mouth coordinates are $\mathrm{N} 43.186174^{\circ}$, E27.885542 ${ }^{\circ}$, with an altitude of $4 \mathrm{~m}$. According to KöppenGeiger climate classification, the climate in the area is humid subtropical with mediterranean influences in summer, but specially continental influences in autumn-winter (Cfa) (Peel et al., 2007). The specific Black sea climate is milder than in the inland parts of the country and the sea influence lowers the effect of the occasional cold air masses from the north-east. For the period 2000-2019, the average precipitation is $540.3 \mathrm{~mm}$, and the average annual air temperature is $13.8^{\circ} \mathrm{C}$ (WeatherOnline Ltd., 2021).

The spring water convergences with a short drainage channel that enters an artificial marine channel which connects Varna Lake with the Black Sea.

On 24th of February, 2020, several individuals of the green swordtail were collected using a standard hydro-biological hand net. The specimens were fixed in $70 \%$ ethanol.

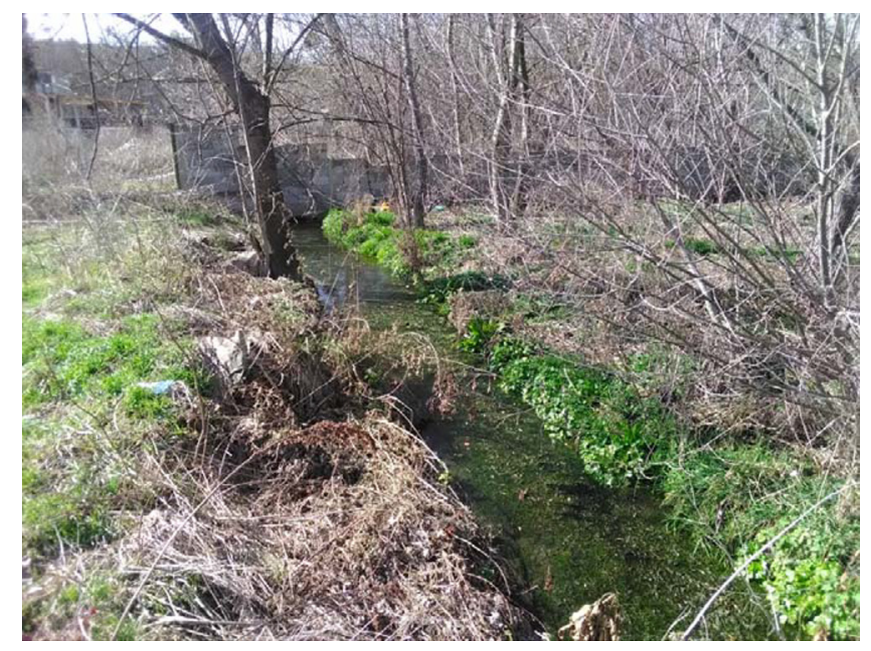

Fig. 1. The studied outflow channel of the warm spring.

Taxonomical determination was conducted using the species-specific characteristics indicated by Froese and Pauly (2019). Basic morphological parameters (e.g. total length, length of the sword, number of scales in lateral line, number of rays in dorsal and anal fins) were measured (Tab. 1). All individuals were classified as adult or juvenile according to their gonad development. The sex in adults was noted and existing of embryos in females was documented after dissection.

Water temperature was measured in February, 2020 (winter) and in August, 2020 (summer). Information about chemical composition was provided by the administration of the Varna Municipality who is managing the mineral springs in the area.

The invasiveness screening tool for non-native freshwater fishes (FISK v2, Lawson et al., 2013), calibrated for the Balkan region (Simonović et al., 2013), was used for the risk assessment of the green swordtail potential invasiveness in the coastal freshwater bodies of the Eastern Balkans.

First observation of numerous green swordtail individuals in studied site was during the summer of 2012. The existence of the population was confirmed in the middle of January, 2020. In total, 24 green swordtail specimens were collected and more than 150 individuals were observed during the field work in February, 2020. The total length of the fish varied within the range of 9-90 $\mathrm{mm}$ (average: $39 \mathrm{~mm}$ ). With regards to age and sex composition, nine juveniles, five adult males and ten adult females were caught (Tab. 1). The smallest matured individual was $37 \mathrm{~mm}$ long, and the largest immature one was $17 \mathrm{~mm}$. In general, females were larger than males, as the average total length was respectively 58 and $49 \mathrm{~mm}$. Spines were missing in dorsal and anal fin while soft rays were respectively $12-13$ and 10 . Lateral line contained 26-27 scales. Larger mature males had longer caudal appendage than younger ones and its percentage of the body length increased with the fish size from $27 \%$ up to $70 \%$. All adult females, except one, had eggs in different embryonic development (Fig. 2).

A photomicrograph of the gonopodial distal part of green swordtails caught is shown in Figure 4. It is well visible that the terminal segment of gonopodial ray 3 is transformed into a 
Table 1. Age-sex composition and meristics of the collected $X$. hellerii specimens.

\begin{tabular}{|c|c|c|c|c|c|c|}
\hline ID & Sex & Scales in lateral line & Dorsal soft rays & Anal soft rays & Total length & Standard length \\
\hline 1 & $\mathrm{~F}$ & 27 & 12 & 10 & 76 & 58 \\
\hline 2 & M & 26 & 13 & 10 & 57 & 43 \\
\hline 3 & $\mathrm{~F}$ & 27 & 13 & 10 & 60 & 45 \\
\hline 4 & M & 27 & 13 & 10 & 57 & 44 \\
\hline 5 & $\mathrm{~F}$ & 27 & 12 & 10 & 59 & 44 \\
\hline 6 & M & 26 & 13 & 10 & 48 & 36 \\
\hline 7 & M & 26 & 12 & 10 & 45 & 36 \\
\hline 8 & $\mathrm{~F}$ & 27 & 13 & 10 & 51 & 42 \\
\hline 9 & $\mathrm{~F}$ & 26 & 13 & 10 & 75 & 57 \\
\hline 10 & $\mathrm{~F}$ & 27 & 13 & 10 & 90 & 69 \\
\hline 11 & M & 26 & 12 & 10 & 40 & 30 \\
\hline 12 & $\mathrm{~F}$ & 27 & 13 & 10 & 54 & 41 \\
\hline 13 & $\mathrm{~F}$ & 27 & 12 & 10 & 41 & 30 \\
\hline 14 & $\mathrm{~F}$ & 27 & 12 & 10 & 38 & 29 \\
\hline 15 & $\mathrm{~F}$ & 27 & 12 & 10 & 37 & 28 \\
\hline 16 & Juvenile & $\mathrm{NM}$ & $\mathrm{NM}$ & $\mathrm{NM}$ & 16.5 & $\mathrm{NM}$ \\
\hline 17 & Juvenile & NM & NM & $\mathrm{NM}$ & 14.5 & NM \\
\hline 18 & Juvenile & NM & NM & NM & 10.5 & NM \\
\hline 19 & Juvenile & NM & NM & NM & 9.5 & NM \\
\hline 20 & Juvenile & NM & NM & NM & 10 & NM \\
\hline 21 & Juvenile & $\mathrm{NM}$ & $\mathrm{NM}$ & NM & 10 & $\mathrm{NM}$ \\
\hline 22 & Juvenile & NM & NM & NM & 10 & NM \\
\hline 23 & Juvenile & NM & NM & NM & 9 & NM \\
\hline 24 & Juvenile & NM & NM & NM & 9 & NM \\
\hline
\end{tabular}

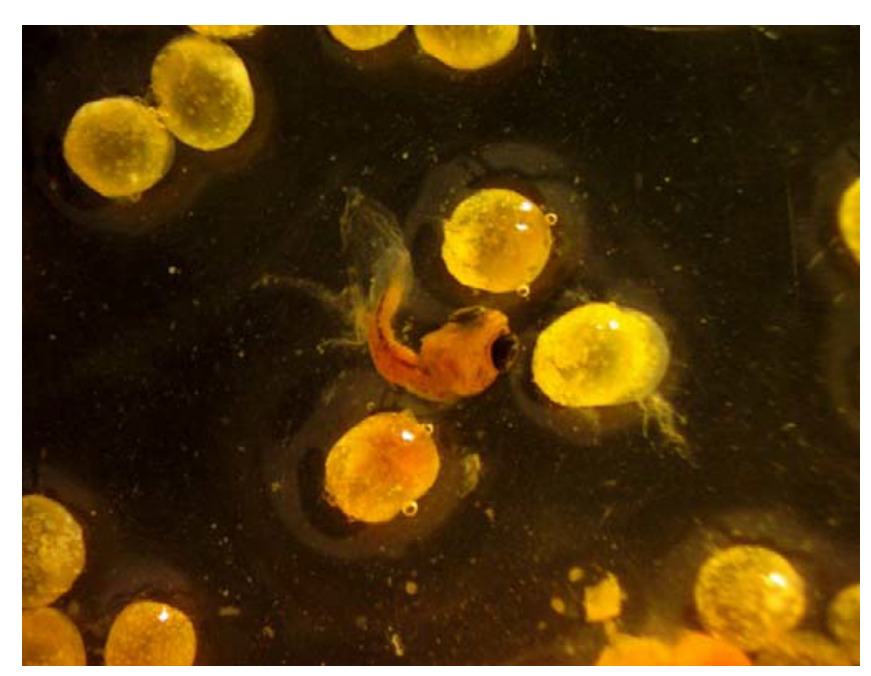

Fig. 2. Eggs and an embryo of $X$. hellerii.

crescent-shaped hook and blade pointed distally. The angle between the main section of ray $4 \mathrm{a}$ and its backward curve over the blade is greater than $90^{\circ}$. Ray $4 \mathrm{p}$ is characterized with reduced in size and number distal serrae and relatively slim proximal serrae. A large claw is formed by the terminal segment of ray $5 \mathrm{a}$ and it is several times bigger than the distal serrae of ray $4 \mathrm{p}$.

Described morphological characteristics of the gonopodium corresponded to the description for $X$. hellerii given by Kallman et al. (2004). Implementation of the species-specific morphological key set proposed by Froese and Pauly (2019), allowed us to conclude that individuals caught belonged taxonomically to the species $X$. hellerii.

The colour of all individuals except those in larval stage was dark orange (Fig. 3), which is the most common coloration in captive-bred ornamental varieties (CABI, 2020). Fish from wild populations are usually light greenish in colour with a red or brown mid-lateral stripe (CABI, 2020).

With regards to water temperature of the assessment area, in February it was $21^{\circ} \mathrm{C}$ and in August $27^{\circ} \mathrm{C}$. We could not obtain official data, but it seems that the seasonal fluctuation of water temperature is within several degrees. According to Bulgarian legislation, the water in the assessment area is drinkable and do not pose a risk to human health (CMRB, 2004).

In green swordtail, the female reproductive cycle is controlled by water temperature, ceasing when it falls below $15^{\circ} \mathrm{C}$ or increases above $30^{\circ} \mathrm{C}$, with optimal values from $22^{\circ} \mathrm{C}$ to $26^{\circ} \mathrm{C}$ (Milton and Arthington, 1983). Therefore, we can expect that the examined green swordtail population reproduces continuously throughout the year.

FISK outcome for the green swordtail in the assessment area scored 21. A calibration threshold of 9.5 categorized the species in 'high risk' with a further detailed categorization as per Britton et al. (2010) into 'moderately high risk' (values in the interval from 9.5 to 25 ).

The high invasive risk of green swordtail is primarily due to its wide environmental tolerances, the ability to colonise disturbed habitats, its trophic opportunism, short life cycle in combination with ability for extended spawning season and the 

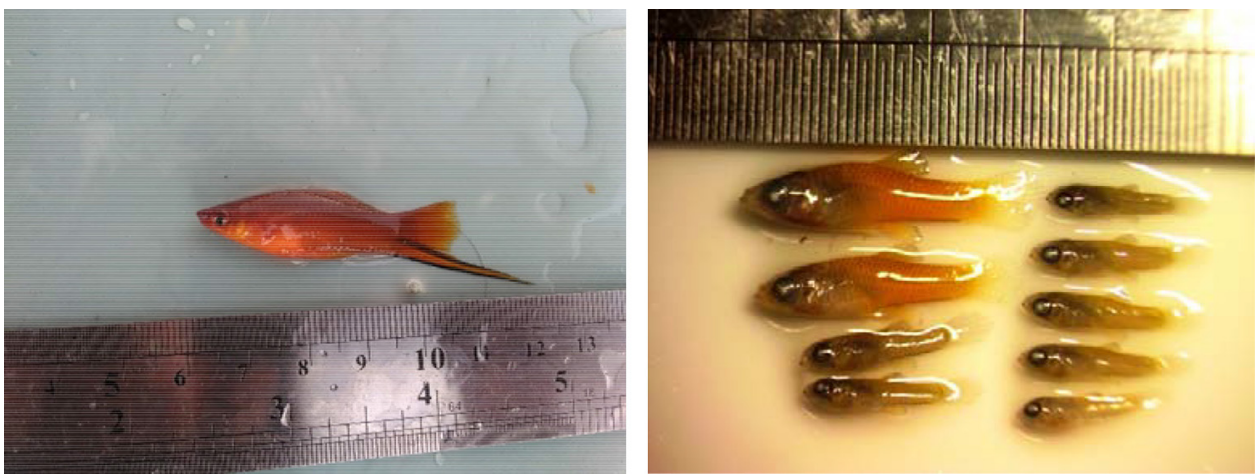

Fig. 3. Male adult on the left and juveniles on the right of the green swordtail.

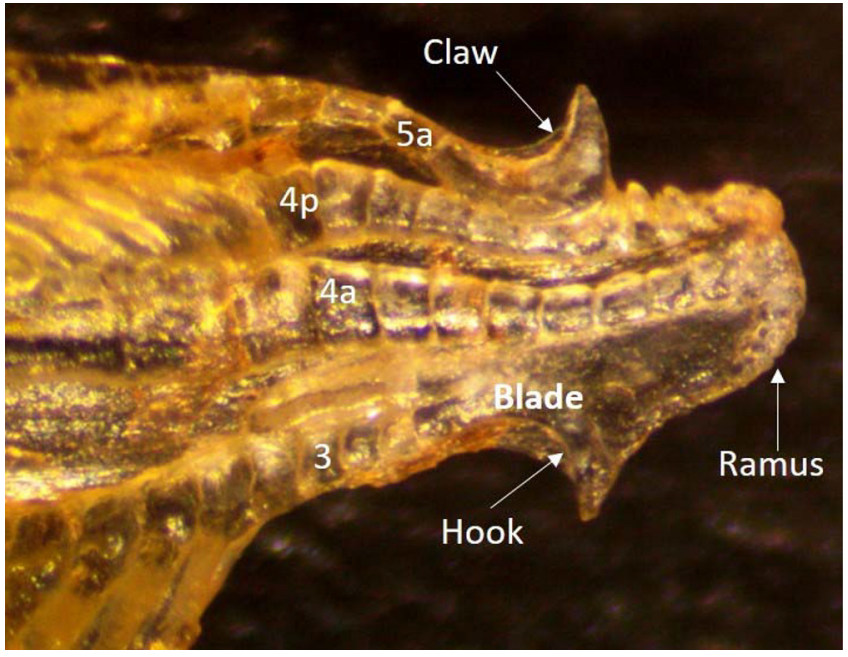

Fig. 4. Photomicrograph of the distal part of a gonopodium of $X$. hellerii from the assessment area.

ovoviviparity. Furthermore, the species is already proved to be invasive in many countries (CABI, 2020), and it experiences wide and continuous human-mediated translocation and release.

The low level of climate match between the climate in the assessed area and the species preferences prevents the species to colonise easily new habitats in the area. Winter temperatures in Varna lake, as well as in the channel that connects it with Black sea, are approximately $5.5^{\circ} \mathrm{C}$ at the surface and $4.8^{\circ} \mathrm{C}$ close to the bottom (Dineva, 2015), which is a bit below the species lethal temperature minimum (from $5.5^{\circ} \mathrm{C}$ to $11.3^{\circ} \mathrm{C}$ ) reported by Tuckett et al. (2016). The escaped populations exhibit lower chronic lethal temperature minimum than the farmed ones (Tuckett et al., 2016). However, the studied population is not exposed to significant adaptation triggers due to very slight annual changes in its habitat conditions.

Salinity was considered as another key limit for the species to colonise new habitats in the area. The warm freshwater from the spring convergences with a channel that has approximate salinity of $15 \mathrm{ppt}$ with a slight seasonal fluctuation (Dineva, 2015). Although such values are out of the species habitat preference (Englund, 2002), they can be tolerated for some time according to Eagderi et al. (2018). This means that the channel and the Varna Lake do not represent a secure migration barrier. Indeed, there exists a risk that the green swordtail will migrate through the channel and Varna Lake and will reach and colonize upstream brackish and freshwater wetlands that match species preferences.

Climate change and the trend of warmer winters (Stanev et al., 2019) are prerequisites for species acclimatization to the temperature out of the thermal spring. Therefore, the potential of the green swordtail to colonise new habitats is increasing with such facilitated acclimatization. According to FISK results, we conclude that the green swordtail poses a high risk to become a new invasive species in Southern Europe.

\section{References}

Britton JR. Cucherousset J, Davies GD, Godard MJ, Copp GH. 2010. Non-native fishes and climate change: predicting species responses to warming temperatures in a temperate region. Freshw Biol 55: $1130-1141$

CABI. 2020. Xiphophorus hellerii. In: Invasive Species Compendium. Wallingford, UK: CAB International. Available on: https:// www.cabi.org/isc/datasheet/59751. Downloaded on 08 August 2020.

CMRB - Council of Ministers of the Republic of Bulgaria. 2004. Ordinance on the requirements for bottled natural mineral and spring waters for drinking purposes [in Bulgarian: Наредба за изискванията към бутилираните натурални минерални, изворни и трапезни води, предназначени за питейни цели]. Adopted by a decree of the Council of Ministers of the Republic of Bulgaria $178 / 23.07 .2004$.

Daniels A, Maiz-Tome L. 2019. Xiphophorus hellerii. The IUCN Red List of Threatened Species 2019: e.T191780A2002911. https://dx. doi.org/10.2305/IUCN.UK. 2019-2.RLTS.T191780A2002911.en. Accessed on 14 August 2020.

Dineva S. 2015. The system of the Beloslav and the Varna lakes: an evolving water environment. Bulgar J Agric Sci 21(Supplement 1): 111-115.

Eagderi S, Poorbagher H, Parsazadeh F. 2018. Effect of salinity on the body shape of sword tail, Xiphophurus helleri, during early developmental stage. Int J Ornament Aquat Res 1: 1-7.

Englund RA. 2002. The loss of native biodiversity and continuing nonindigenous species introductions in freshwater, estuarine, and wetland communities of Pearl Harbor, Oahu, Hawaiian Islands. Estuaries 25: 418-430. 
Esmaeili HR, Coad BW, Gholamifard A, Nazari N, Teimory A. 2010. Annotated checklist of the freshwater fishes of Iran. Zoosystem Rossica 19: 361-386.

Froese R, Pauly D. Editors. 2019. Xiphophorus hellerii Heckel, 1848. FishBase. Available on: https://www.fishbase.de/summary/XIPHO PHORUS-HELLERII.html. Downloaded on: 08 August 2020.

GBIF - Global Biodiversity Information Facility. 2019. GBIF Secretariat. GBIF backbone taxonomy: Xiphophorus hellerii Heckel, 1848. Global Biodiversity Information Facility, Copenhagen. Available on: https://www.gbif.org/species/8246728. Downloaded on: 08 August 2019.

Golani D, Mires D. 2000. Introduction of fishes to the freshwater system of Israel. Israeli J Aquacult 52: 47-60.

Holčík J. 1991. Fish introductions in Europe with particular reference to its central and eastern part. Can J Fish Aquat Sci 48(Suppl. 1): $13-23$.

Kallman KD, Walter RB, Morizot DC, Kazianis S. 2004. Two New Species of Xiphophorus (Poeciliidae) from the Isthmus of Tehuantepec, Oaxaca, Mexico, with a Discussion of the Distribution of the $X$. clemenciae Clade. Am Museum Novit 3441: $1-34$.

Lawson LL Jr, Hill JE, Vilizzi L, Hardin S, Copp GH. 2013. Revisions of the fish invasiveness screening kit (FISK) for its application in warmer climatic zones, with particular reference to peninsular Florida. Risk Anal 33: 1414-1431.

Larentis C, Baldasso CM, Kliemann KCB, Neves PM, Zavaski GA, Sandri ML, Ribeiro CA, de Sousa Simoes Xavier DP, de Oliveira Nagasawa Costa G, Delariva RL. 2019. First record of the nonnative Xiphophorus hellerii (Cyprinodontiformes: Poeciliidae), in the Iguazu River Basin, Paraná, Brazil. J Appl Ichthyol 35: 1164-1168.

Maciaszek R, Marcinek D, Eberhardt M, Wilk S. 2019. Alien freshwater fish, Xiphophorus interspecies hybrid (Poeciliidae) found in artificial lake in Warsaw, Central Poland. World Sci News 132: 291-299.
Maddern MG, Gill HS, Morgan DL. 2011. Biology and invasive potential of the introduced swordtail Xiphophorus hellerii Heckel (Poeciliidae) in Western Australia. Aquat Conserv 21: 282-291.

Miller RR. (with the collaboration of Minckley WL and Norris SM). 2005. Freshwater Fishes of Mexico. University of Chicago Press, Chicago, Illinois $490 \mathrm{p}$.

Milton DA, Arthington AH. 1983. Reproductive biology of Gambusia affinis holbrooki Baird and Girard, Xiphophorus helleri (Gunther) and X. maculatus (Heckel) (Pisces; Poeciliidae) in Queensland, Australia. J Fish Biol 23: 23-41.

Musil J, Jurajda P, Adamek Z, Horky P, Slavık O. 2010. Non-native fish introductions in the Czech Republic - species inventory, facts and future perspectives. $J$ Appl Ichthyol 26: 38-45.

Nico L, Fuller P, Neilson M. 2021. Xiphophorus hellerii Heckel, 1848: U.S. Geological Survey, Nonindigenous Aquatic Species Database, Gainesville, FL. Available on: https://nas.er.usgs.gov/ queries/factsheet.aspx?SpeciesID=869. Accessed on: 18 January 2021.

Peel MC, Finlayson BL, McMahon TA. 2007. Updated world map of the Köppen-Geiger climate classification. Hydrol Earth Syst Sci 11: $1633-1644$.

Simonović P, Tošić A, Vassilev M, Apostolou A, Mrdak D, Ristovska M, Kostov V, Nikolić V, Škraba D, Vilizzi L, Copp GH. 2013. Risk identification of non-native freshwater fishes in four countries of the Balkans Region using FISK. Mediterran Mar Sci 14: 369-376.

Stanev VE, Peneva E, Chtirkova B. 2019. Climate change and regional ocean water mass disappearance: case of the black sea. J Geophys Res: Oceans 124.

Tuckett MQ, Ritch LJ, Lawson MK, Hill EJ. 2016. Variation in cold tolerance in escaped and farmed non-native green swordtails (Xiphophorus hellerii) revealed by laboratory trials and field introductions. Biol Invasions 18: 45-56.

WeatherOnline Ltd. 2021. Historical Weather Data for Varna, Bulgaria (1982-2021). Available on: weatheronline.co.uk. Downloaded on 01.06.2021.

Cite this article as: Pandakov P, Barzov Z, Moldovanski R, Huđek H. 2021. First confirmed record of an established population of green swordtail (Xiphophorus hellerii Heckel, 1848) in Europe. Knowl. Manag. Aquat. Ecosyst., 422, 31. 